УДК 340.12

DOI https://doi.org/10.32837/pyuv.v0i2(27).179

\author{
C. O. Опішняк \\ студентка юридичного факультету \\ Київського національного університету ілені Тараса Шевченка
}

\title{
АНТРОПОЛОГІЯ ВЛАДИ: СТАНОВЛЕННЯ УЯВЛЕНЬ ТА СУЧАСНИЙ СТАН
}

Влада є невід'ємною складовою частиною будьякої держави, оскільки саме здійснення владного впливу забезпечує належну організацію суспільства та підтримання правопорядку. Деякі дослідники висловлюють думку, що влада є опорою всіх соціальних відносин. 3 одного боку, ми живемо у період, коли в суспільстві через низку суб'єктивних та об'єктивних факторів сформувалось негативне ставлення до державної влади, що породжує правовий нігілізм та небажання дотримуватись імперативних приписів держави зі сторони громадян. 3 іншого боку, це також час докорінної зміни соціального розвитку та соціально-політичної організації життя, утвердження такого інституту, як громадянське суспільство.

Тому важливо дослідити походження феномена влади i, виходячи з отриманих результатів, підтвердити чи спростувати тезу, що влада породжена не лише певними соціальними факторами, а й випливає з самої природи людини, їі потреб, інтересів. Вивчення проблеми правової антропології влади дасть змогу визначити співвідношення людини та влади, зрозуміти, чи є обгрунтованим їхнє ототожнення та приписування владі властивостей антропного характеру.

Державна влада як здатність держави за допомогою певних засобів здійснювати вплив на поведінку суб’єктів є досить дослідженою, однак доволі мало уваги було присвячено саме вивченню сутності та природи явища влади з правової точки зору. Перші спроби дати визначення поняття «влада» були зроблені Платоном та Аристотелем, у подальшому цю тему досліджували філософи доби Просвітництва, а саме Т. Гоббс та Г. Спенсер. Значним є внесок у дослідження цього питання робіт В.Ф. Халіпова, який дав визначення антропологї̈ влади як науки про владу над людьми, що спирається на соціоприродні дані, здібності та можливості людини [1, с. 248]. В.В. Бочанов присвятив двотомну працю під назвою «Антропологія влади. Хрестоматія політичної антропології» власному дослідженню та зібранню робіт інших авторів, що вивчали виникнення феномена влади в суспільстві, її функціонування в різних культурах на різних рівнях соціальної ієрархії з ідеологічного, психологічного та символічного аспектів. I, звичайно, не можна не згадати В.В. Завальнюка, що написав цикл статей на тему юридичної антропології влади, в яких, досліджуючи цю про- блему, дійшов висновку, що антропологічний підхід відкриває нетрадиційні шляхи до осмислення відносин особистості та державної влади [2, с. 9].

Метою пропонованої статті є виокремлення антропологічних підходів до розуміння влади серед теорій походження держави і влади, формування пропозицій щодо вдосконалення цього розуміння в сучасній правовій науці, обгрунтування власного антропологічного доктринального бачення влади в площині права, визначення сфер, в яких можливе застосування антропологічного підходу до дослідження влади.

Влада відіграє суттєву роль в існуванні людини, оскільки вона супроводжує їі не лише у сфері державної організації та управління, але й у багатьох інших: це влада батьків над дитиною, роботодавця над підлеглим, церкви над релігійною особою та навіть у стосунках між двома друзями проглядається більший вплив одного на іншого. Такий погляд на відносини, що нас оточують, змушує поставити перед собою питання, якою є природа влади. Відповідь на це питання намагаються знайти в межах науки антропології права. В.В. Завальнюк у своїх працях висловив думку, що саме наука антропології влади, по-перше, охоплює сукупність уявлень про існування людини у світі влади, по-друге, про сприйняття влади підвладними i, по-третє, здатна похитнути нібито незаперечну істину про виключно соціальну природу державної влади та протистояти поширенню уявлень про державу як суто бюрократичний та/або правовий режим. Юридична антропологія звертає увагу саме на те, що влада, в тому числі і державна, породжена не тільки соціальними факторами, але і природою людини, їі інстинктами, потребами, почуттями, інтересами [2, с. 5]. Наслідком цього є те, що влада «олюднюється», тобто ототожнюється 3 певним живим організмом, якому притаманні основні риси людини як біологічної та соціальної істоти.

Варто зазначити, що антропологічне розуміння влади є одним із найдавніших підходів в історії правової та державницької думки. Його можна простежити в різних теоріях походження держави і влади, зокрема в органічній, психологічній, біхевіористській, договірній та патріархільній. Звичайно, об'єднання ідей у певні теорії є умовним, оскільки одне вчення може містити ознаки кількох різних теорій, проте в нашому дослі- 
дженні важливим є те, що кожна з цих концепцій містить риси антропологічного розуміння державної влади.

Відповідно до органічної теорії, держава - це організм, який народжується, живе, старіє і вмирає. Деякі елементи органіцизму містилися в роботах Платона. Для нього суспільство являє собою «велику людину», якусь самостійну реальність, що має свою внутрішню гармонію, особливі закони рівноваги. Платон порівнював структуру і функції держави зі здатністю і характеристиками людської душі, в ідеальній державі він бачив справедливу людину, яка має ті самі інтелектуальні здібності та пристрасті, що й людина.

За Арістотелем, держава в багатьох відношеннях нагадує живий людський організм і на цій підставі він заперечував можливість існування людини як істоти, ізольованого від суспільства. Свої погляди Аристотель аргументував таким порівнянням: як руки і ноги, відняті від людського тіла, не можуть самостійно функціонувати, так i людина не може існувати без держави.

У сучасному розумінні основні положення органічної теорії були сформульовані ще на початку XIX ст. представниками європейського консерватизму Е. Берком, Ж. де Местром, Л. де Лабанд та іншими авторами. В основі різних їі варіантів лежать уявлення про державу як про живий організм, що складається 3 невіддільних один від одного складових частин, якими є різні стани, колективи, інститути тощо, об'єднані єдиною волею і спільними інтересами [3].

Надалі найважливіші положення цієї теорії були сприйняті також представниками інших течій європейської суспільно-політичної думки, зокрема Г. Спенсером, який вважав державу результатом органічної еволюції, різновидом якої є еволюція соціальна. Згідно з його підходом, жива істота, людина, суспільство та його політична організація, тобто держава, володіють рисами схожості та відмінності. Держава - це суспільний організм, що складається з окремих людей, подібно до того, як живий організм складається з кліток. Важливою стороною теорії є твердження, що держава утворюється одночасно зі своїми складниками - людьми і буде існувати, поки існує людське суспільство. На думку Спенсера, воля держави виражається в законах, уряд ототожнюється 3 мозком, робітники і селяни - з ногами і руками, а рухи і зв'язки - з нервами [4]. Таким чином, у межах органічної теорії влада прирівнюється до живої істоти, що має свої думки, почуття, бажання, складається 3 певних частин, що не можуть існувати одна без одної, а отже, хоча антропологія влади почала виокремлюватись науковцями як самостійна наука порівняно нещодавно, перші елементи антропологічного підходу до розуміння влади виникли ще за часів античності.
Патріархальна теорія грунтується на положенні, що держава виникла 3 патріархальної сім'ї в результаті їі розростання та об'єднання сімей у племена, союзи племен, народності (цьому сприяло збереження переказу про їх загальне виникнення). Риси цієї теорії є і у вченні Аристотеля, за яким селища, що утворилися, утворили державу. Держава виникає як результат природного потягу до сімейних взаємин, спілкування, а влада государя (монарха) є продовженням влади батька (патріарха) в сім'̈̈, що має державно-власницький характер на зразок домовласницького [5]. Конфуцій також розглядав державу як велику сім'ю, тобто держава - це споріднені зв'язки людських істот. Як він стверджував, влада має грунтуватися не на безликому і загальному законі, що заснований не на свавіллі тирана, а на мудрості доброчесного правителя, який є батьком народу [3].

Найяскравішим представником патріархальної теорії є англійський мислитель XVII ст. Р. Фільмер у праці «Патріархія, або Захист природного права королів» (1642). Грунтуючись на Біблії, він сформулював положення, згідно з яким першолюдина Адам як родоначальник людства був першим батьком i першим монархом. Вихідною формою правління, встановленої Богом і заснованої на божественному праві, є монархія [3]. Отже, кожен із прихильників цієї теорії ототожнював державну владу з однією людиною, а значить, владі з точки зору патріархальної теорії притаманні усі властивості людської істоти: характер, бажання, здатність мислити тощо. Згідно з цим підходом, влада не може існувати окремо від особи, оскільки сама людина її уособлює.

Психологічна теорія подана ідеями Г. Гарда та Л. Петражицького. Суть теорії полягає в утвердженні психологічної потреби людини проживати в рамках організованого суспільства, а також із почуттям необхідності колективної взаємодії. Ïї прибічники визначали суспільство і державу як суму психічних взаємодій людей та їх різних об'єднань. Вони вважали, що суспільство і держава є послідовністю психологічних закономірностей розвитку людини. Психіка людини, її імпульси та емоції визначають головну роль не тільки у пристосуванні людини до умов, що змінюються, але й у виникненні держави і права [4]. Антропологізм у межах психологічної теорії виявляється в тому, що влада визначається як прояв властивостей людської психіки, потреби підкорятися, усвідомлення залежності від еліти, розуміння справедливості визначених варіантів дії і відносин, а також природної потреби людини наказувати. Можна сформувати головну тезу цієї теорії: людина не може існувати без влади.

Біхевіористська теорія (від англ. behavior «поведінка») розглядає владу як особливий тип поведінки людей, коли одні домінують (панують) 
над іншими, а інші підпорядковуються їм. Влада зводиться до взаємодії людей, базується на можливості зміни поведінки індивідів. Влада розглядається як першопричина, як детермінанта дії особи. Звідси і висновок про необхідність контролю, здійснення впливу на поведінку людей. Так, американський дослідник Б. Скіннер розглядав людину як пасивний об єкт, не здатний до ініціативи, зате з природними задатками підпорядковуватися. Він обірунтував необхідність цілеспрямовано впливати на людей для одержання бажаної зміни їхньої поведінки. Ці ідеї було використано в деяких урядових програмах, спрямованих на зміну поведінки людей, включаючи і сферу політичних відносин [6]. Таким чином, антропологічний вимір влади полягає в тому, що вважається, що влада є рушійною силою будь-яких дій людини, незалежно від того, яку позицію особа у відносинах займає: управляє чи підпорядковується.

Договірна (природно-правова) теорія, представниками якої є Г. Гроцій, Б. Спіноза, Т. Гоббс, Дж. Локк, Ж⿱乛.-Жћ. Руссо, Я. Козельський, М. Радищев, I. Кант, грунтується на ідеї виникнення держави в результаті угоди (договору) як акту розумної волі людей. Об'єднання людей в єдиний державний союз розглядається як природна вимога збереження людського роду і забезпечення справедливості, свободи і порядку.

Всі вони розглядали державу як продукт людського розуму і діяльності, зумовленої прагненням людей до виживання. Можна виділити два варіанти договору державотворення, запропонованих представниками цієї теорії:

1) договір між правителем і людьми (Т. Гоббс), коли правителю передається частина природжених прав, які він повертає громадянам зі своїх рук після державотворення і виступає їх гарантом (суспільний договір-підпорядкування);

2) договір людей один 3 одним, усіх з усіма (Ж⿱.-ЖЖ. Руссо), що передбачає невідчуження, збереження природних прав за індивідами при укладанні договору одного з одним про державотворення (суспільний договір-об'єднання). У будь-якому разі передбачається забезпечення природних прав i свобод особи в межах держави - це визначає прогресивність варіантів цієї теорії.

Договірною теорією звертається увага на індивідуалістичні засади на ранніх етапах життя людства, розвиненість розуму людей періоду переходу до державності від «природного стану», усвідомленість їхнього підходу до необхідності вступу в договір про утворення держави [5]. Антропологізм полягає у тому, що вважається, що люди уклали між собою договір, відповідно до якого наділили окремих осіб владою для здійснення певних функцій.

У цієї теорії є чимало противників, які наполягають на тому, що нею перебільшується розвиненість розуму людей, однак варто згадати про деякі історичні події. Наприклад, англійські пуритани, що прибули до Північної Америки на кораблі «Мейфлауер» у 1620 р., уклали між собою договір про заснування власної колонії, а також взяли на себе обов'язок дотримуватись законів, що існують на благо колонії.

Ми перерахували основні теорії, в яких значною мірою простежується антропологічний підхід до походження влади. Однак в інших теоріях так чи інакше також проглядається антропологічний підхід. Зокрема, представники багатофакторної та олігархічної теорій (Ф.Ф. Кокошкін, М.М. Ковалевський, Б. Шантебу) повністю або частково пов'язували причини виникнення держави з тими здібностями, які первісна людина бачила у племінних ватажків, жерців, шаманів, чаклунів, адже вони могли робити щось таке, на що були нездатні усі інші. Їхня «магічна сила» робила громаду залежною від їхньої діяльності, що й стало зародком державної влади [7, с. 210]. 3 огляду на викладене можна зробити висновок, що категорія "походження держави та влади» 3 усіх елементів теорії держави зазнала великого впливу антропологізму.

Важливо також згадати, що з позицій правової антропології можна охарактеризувати форму держави, хоча загальноприйнятним є визначення як системи форм інституційної, територіальної i політичної організації та здійснення державної влади в країні, яке, як правило, ніколи не включає антропологічної складової [5]. На думку В.В. Завальнюка, така відсутність суттєво збіднює, зокрема визначення державного режиму, який тісно співвідноситься 3 державною владою. Наприклад, тоталітарним можна вважати лише той режим, який передбачає певні людські властивості правителя: наявність у нього харизми лідера, здатності нав'язувати свою волю та свою ідеологію підвладним не раціональними способами, а навпаки. Здавалось би, що обожнювання політичних лідерів має суто психологічний вимір i не має нічого спільного з правом, однак насправді він має і юридичний вимір, оскільки може закріплюватися у антропоморфній титулатурі. Яскравим прикладом слугує титулатура Й. Сталіна «Батько народів», що набула характеру офіційної [2, с. 7], або титул, що носили китайські імператори, - «Син неба».

Антропологічний підхід до визначення походження та сутності влади застосовується і в наш час. Виявляється це в тому, що часто суспільство ототожнює державну владу з конкретними людьми i, таким чином, приписує їй певні прагнення, бажання, цілі тощо. В.В. Завальнюк зазначає, що в суспільній правосвідомості державі приписуються властивості, що можуть бути притаманними лише людині як біологічній та соціальній істоті: 
1) наявність власних інтересів, що згідно з поширеним переконанням у суспільстві йдуть у розріз з інтересами самого народу, хоча і суперечить сутності демократії;

2) здатність викликати почуття та емоції (заздрість, любов, ненависть, неповагу, шану тощо). Це зумовлюється тим, що ставлення населення до конкретних політичних сил, які зосередили в своïx руках політичну владу в конкретний історичний відрізок часу, трансполюється на ставлення до держави як інституту загалом;

3) здатність підтримувати певні стосунки з іншими державами, які притаманні саме людським відносинам, зокрема такі як дружба чи ворожість.

3 огляду на це можна дійти висновку, що в суспільній думці державна влада набуває ознак людини через те, що вона ототожнюється з конкретними людьми, які в певний історичний період обіймають найвищі державні посади (президент, канцлер, прем'єр-міністр тощо) та 3 політичною силою, яка має більшість у представницькому органі влади. Схожу ідею висловив Л.С. Маммут, який стверджує, що в пам'яті суспільства державність закарбовується в одній із двох іпостасей: або у вигляді якоїсь асоціації індивідів, або у вигляді окремої особи $[8$, с. 85-97].

Не варто вважати, що антропологічний підхід має значення лише в межах доктринального дослідження держави та влади. Насправді він застосовується і на практиці. В.В. Завальнюк наводить як приклад антропологічний вимір державних інститутів та державної служби, що застосовується законодавцями. Це виявляється у нормативних вимогах, що встановлюються для обійняття певної посади: це досягнення певного віку, певний рівень компетентності, стаж роботи, доброчесність тощо [2, с. 7]. Наприклад, в Австрії на посаду судді може бути призначений лише дієздатний австрійський громадянин із бездоганною репутацією, який завершив повний курс юридичної освіти в університеті (з отриманням диплому), має не менше одного року судової практики та отримав позитивну характеристику не менше трьох суддів наставників [9, с. 350]. Якщо говорити про Велику Британію, то є ще один важливий аспект: колегія для розгляду справ про правопорушення дитини має містити хоча б одного суддю-жінку $[10$, с. 89].

Це означає, що антропологічний вимір стосується не лише певних психологічних властивостей людини, що переносяться на інститути влади, але і деяких фізичних ознак. До них можна зарахувати стать, расу, вік, національність тощо. Оскільки питання гендерної рівності є дискусійною проблемою у наш час, хотілось б розглянути антропологічний вимір саме на цьому прикладі.

Чимало дослідників стверджують, що гендерні відносини не можна розглядати окремо від питання влади, адже множинні маскулінності (як і фемінності) не можуть бути рівними. Владний вимір гендерних відносин пронизує як громадську, так і приватну сфери суспільства [11, с. 6]. Дослідник Р. Коннел під структурою влади розуміє не тільки державу, але й усю ієрархію виробничих, владних відносин і відносин катексису (емоційні відносини). Тому йдеться не лише про розподіл політичної влади у суспільстві, а й про весь спектр владних відносин, стрижень яких становить зв' зок влади і сили з маскулінністю [12]. В аспекті співвідношення влади та гендеру найважливіше зазначити, що навіть у наш час залишились гендерні стереотипи, які визначають, яким має бути місце чоловіка та жінки в суспільстві, управлінні державою тощо.

Дослідники виокремлюють три групи гендерних стереотипів. Перша група гендерних стереотипів базується на відповідних уявленнях про психологічні риси та якості особистості чоловіків і жінок. Згідно з цими стереотипами, чоловіки і жінки є протилежностями, тобто чоловікам приписується активне, творче начало, здатність розв'язувати проблеми, застосовувати розвинене логічне мислення та власну компетентність; жіноче ж начало - природно-репродуктивне, і тому жінка має бути покірною, залежною.

В основу виокремлення другої групи гендерних стереотипів покладені соціальні начала. Ця група стереотипів закріплює професійні ролі чоловіків і жінок. Для жінки головними є ролі сімейні (дружина, мати, господарка), а для чоловіка - ролі професійні.

До третьої групи гендерних стереотипів вчені зараховують стандартизовані уявлення, що пов'язані з відмінностями у змісті праці - жіночої і чоловічої. Місце жінки - у сфері виконавчої та обслуговуючої праці, чоловіка - у сфері інструментальної праці, тобто творчої та керівної.

Усі три групи стереотипів тісно переплетені між собою, мають міцні позиції в суспільстві, а тому суттєво впливають на нього. При цьому часто вплив є латентним і тому дуже важко піддається коригуванню [13]. Це виявляється в тому, що на нормативному рівні в Україні та більшості інших державах світу закріплена рівність чоловіків та жінок, однак на ментальному рівні в суспільній свідомості настільки міцно вкоренились гендерні стереотипи, що часто особа, заангажована певними переконаннями, не усвідомлює те, що діє під їхнім тиском.

Унаслідок існування стереотипів, що склались історично, у державному управлінні потерпає не тільки жінка, а й державна служба, суспільство, оскільки недостатньо використовується жіночий інтелектуальний потенціал з огляду на нерівне представництво жінок і чоловіків на вищих керівних посадах в органах державної влади. Жінки в Україні становлять більшість населення і мають 
справляти відповідний вплив на прийняття політичних рішень. Це, як підкреслюють науковці, уже питання демократії. Варто наголосити: інтереси чоловіків і жінок через їхні фізичні розбіжності не можуть збігатися, тому одні не можуть представляти інших. Українські реалії свідчать, що жіночі погляди часто не беруться до уваги. У результаті склалася ситуація, що негативно впливає на психологічний, економічний і політичний стан усього українського суспільства [14].

B.В. Завальнюк визначає також частиною вивчення антропології влади міф. У наш час поширеною $є$ думка, що міфи давно залишились у минулому і людство у своєму розвитку дійшло до того рівня, коли міфи не справляють ніякого впливу на суспільство. Насправді, це хибне переконання, оскільки йдеться не про ті найдавніші міфи, які пояснювали виникнення світу та людини, а про політичні міфи, які хоча і є надзвичайно поширеними, часто залишаються поза увагою. Вони є впливовим засобом політичної зброї, здатної підкорити, згрупувати й спрямувати людей у стратегічному напрямі. Існують різні визначення політичного міфу, зокрема визначення А. Цуладзе найкраще відображає саме антропологічний вимір влади: це міф, що використовується для реалізації політичних цілей (боротьба за владу, легітимізація влади, здійснення політичного панування, також ним зазначається, що міф дає нам змогу здійснювати комунікаціюіз зовнішнім світом [15].

Надзвичайно актуальним нині є міф «про рятівника-месію», котрий використовується під час кожних передвиборчих перегонів. Кандидат, навколо якого створюється цей міф, сприймається як людина, що, за умови приходу її до влади, зможе вивести країну з кризи або складного становища. Цей міф Ірунтується на архетипі «героя». Таким чином, суспільство на рівні підсвідомості починає поважати цю людину без огляду на справжні вчинки, навколо неї формується ореол народної любові, а тому влада і всі здобутки асоціюються з нею, незалежно від реальної діяльності цієї особи. Яскравим прикладом такого міфу є вже згадувана історична постать Й. Сталін, крім нього, Михайло Горбачов та чимало інших політичних лідерів.

Політичні міфи значною мірою впливають на сприйняття суспільством державних інститутів. Цю думку можна конкретизувати на прикладі сучасного стану такого державного інституту, як прокуратура України. Впродовж тривалого часу в медіа-просторі наполегливо створювався негативний «імідж» цього державного органу та його працівників, навіювалась думка, що всередині процвітає корупція та аморальність, і хоча мало що з цього підтверджувалось фактами, в результаті в суспільстві сформувалось негативне ставлення до цього інституту та всіх його працівни- ків, особливо серед тих, хто ніколи не стикався 3 його роботою та не знає, в чому вона полягає. Таким чином, у свідомості населення було створено «спільного ворога», з яким потрібно боротись. Як наслідок, реформування прокуратури відіграє роль відволікаючого маневру, що на якийсь час «зачаровує свідомість» і відволікає увагу від відсутності вирішення нагальних проблем. До того ж підтримка населення певним чином «легітимізує» всі ті порушення основних принципів українського законодавства та міжнародного права, які здійснюються під час проведення реформування. Важливо також звернути увагу на те, що такий політичний міф породжує деформації правосвідомості в суспільстві, що згодом може спровокувати гірші наслідки, тому необхідно максимально зважено ставитись до цієї сфери антропології влади.

Антропологічний підхід до розуміння влади зумовлює незвичайні для класичної юридичної науки шляхи осмислення та дослідження держави та співвідношення індивідуальної особи та влади. Як видається, крізь призму антропології влади можна досліджувати не лише онтологію влади, але й сприйняття держави та влади суспільством, здійснювати нетрадиційний для юридичної науки аналіз низки правових категорій, наприклад форму держави. Крім того, антропологічний вимір дає змогу удосконалити законотворчий процес, оскільки звертає увагу на поки що декларативне гасло, що держава існує для людини, а її основним завданням є забезпечення інтересів цієї людини. Застосування антропології влади у формуванні державних інститутів забезпечить удосконалення їхнього функціонування шляхом встановлення максимально обгрунтованих та оптимальних нормативних вимог до працівників. 3 огляду на викладене видається, що явище антропології влади є цілковито позитивним і має стати плідним напрямом для подальших досліджень, однак варто не забувати про певні застереження, зокрема про те, що такий аспект антропологічного вивчення влади як міф може призвести до нецільового використання результатів дослідження, наприклад для успішного маніпулювання суспільною свідомістю.

\section{Jimepamypa}

1. Халипов В.Ф. Кратология как система наук о власти : монография. Москва : Республика, 1999. 303 с.

2. Завальнюк В.В. Юридична антропологія влади. Методологія теорії та практики юриспрудениї. Юридичний вісник. 2013. № 4. С. 5-9.

3. Гаджиев К.С. Введение в политическую теорию. Учебник для академического бакалавриата. Юрайт. 2018. URL: https://stud.com.ua/42899/politologiya/ vstup_u_politichnu_teoriyu

4. Вiхров О.П. Теорія держави і права: курс лекцій [Текст] : навч. посібник. Чернігів : Десна Поліграф. 2015. 303 c. URL: https://pidruchniki.com/84511/ pravo/teoriya_derzhavi_i_prava 
5. Скакун О.Ф. Теорія права і держави. Підручник. Правова єдність. Алерта. 2016. URL: https://pidruchniki.com/1262091843012/pravo/ teoriya prava i derzhavi

6. Кирилюка Ф.М. Політологія. Навчальний посібник. Київ : Здоров'я, 2004. 776 с. URL: http://www.info-library.com.ua/books-book-137.html

7. Завальнюк В.В. Антропологізація права: традиції та сучасність : монографія. Одеса : Юрид. л-ра, 2013. $352 \mathrm{c}$.

8. Мамут Л.С. Образ государства как алгоритм политического поведения. Общественные науки и совре менность. 1998. № 6. С. 85-97.

9. Марцинкевич А.М. Вимоги до кандидата на посаду судді: зарубіжний досвід. Наукові записки Львівського університету бізнесу та права. 2011. Вип. 7. C. 349-354.

10. Апарова Т.В. Суды и судебный процесс Великобритании. Англия, Уэльс, Шотландия. Москва : Триада Лтд, $1996.157 \mathrm{c}$.

11. Бабухіна C.А. Гендер і влада: український політичний контекст. Сучасне суспільство: політичні науки, соціологічні науки, культурологічні науки. 2015. C. 4-12.

12. Коннелл Рэйвин. Гендер и власть. Общество, личность и гендерная. Москва : Новое литературное обозрение. 2015.432 с.

13. Поняттятасутьгендеру.Основніпарадигмиінтерпретації гендерних відносин. URL: http://cpk.org.ua/ index.php?option $=$ com content\&view $=$ article\&id $=670$.

14. Воронько Л.О. Гендерна політика в системі державної служби: поняття і сутність. URL: http://academy.gov.ua/ej/ej16/txts/12VLOSPS.pdf

15. Цуладзе А.М. Политическая мифология. Москва : Изд-во «Эксмо», 2003. 384 с.

\section{Анотація}

Опішняк C. O. Антропологія влади: становлення уявлень та сучасний стан. - Стаття.

У статті досліджено проблему науки антропології влади, а саме становлення перших уявлень про неї та сучасні погляди науковців.

Актуальність вибраної теми зумовлюється тим, що в умовах докорінної перебудови соціально-політичної організації держави важливо розуміти співвідношення людини та влади, а також визначити причини та доцільність ототожнення в суспільній свідомості інституту влади 3 живою істотою та наділення його антропними властивостями.

Метою цієї наукової статті є виокремлення антропологічних підходів до розуміння влади в межах теорій походження держави і влади, формування пропозицій щодо вдосконалення цього розуміння у правовій науці, визначення сфер, в яких можливе застосування антропологічного підходу до дослідження влади.

Аналізуються основні теорії походження держави та влади, що містять у собі антропологічний підхід до розуміння феномена влади. На основі цього встановлено, що антропологічний підхід є одним із найдавніших підходів в історії правової та державницької думки, а також те, що категорія «походження держави та влади» 3 усіх елементів науки теорії права та держави зазнала найбільшого впливу антропологізму.

Аргументується, що з позицій антропології можна охарактеризувати форму держави, загальноприйнятне визначення якої ніколи антропологічної складової частини не включає.

Розглядаються причини наділення інституту влади в суспільному сприйнятті суто людськими властивостями. Основною причиною встановлено ототожнення в суспільній думці влади з конкретними людьми, що обіймають найвищі посади, чи політичною силою, котра має більшість у представницькому органі влади.

Визначається практичне значення антропологічного виміру влади. Він застосовується під час законотворчої діяльності, зокрема при встановленні нормативних вимог для зайняття певної посади, відображається в питаннях гендерної, расової, національної рівності.

Обгрунтовано, що антропологічний вимір активно застосовується у політиці у процесі формування так званих політичних міфів, а тому потрібно пам'ятати про певні застереження, оскільки результати дослідження антропології влади можна використовувати не за цільовим призначенням, а для маніпуляції суспільною свідомістю.

Ключові слова: правова антропологія влади, походження влади, природа та сутність феномена влади, антропні властивості влади, антропологічний вимірвлади.

\section{Summary}

Opishniak S. O. Anthropology of power: incipience of conceptions and current state. - Article.

The issues of an anthropology of power, especially the incipience of the first conceptions and current views of scientists, are investigated in this paper.

The relevance of chosen subject is caused by the fact, that in the context of fundamental reformation of the social-political organisation of the state, it is important to realize the correlation of person and power, to determine the reasons and expedience how to identify the institution of power and a living being in the social consciousness, to determine the reasons of the providing the power with the anthropic characteristics.

The purpose of this scientific paper is distinguishing of anthropological approaches to understanding the concept of power within the framework of existing theories of origin of state and power, formulation of proposals regarding the improvement of this understanding within the science, determination of the fields, in which it is possible to apply the anthropological approach to research of power.

Fundamental theories of origin of state and power, which contain the anthropological approach to understanding the concept of power are analysed. It is ascertained, that the anthropological approach is one of the most ancient approaches within the science of the history of legal and political doctrine and that the category "origin of state and power" is the most influenced by the anthropology among other legal scientific categories.

It is reasoned that it is possible to characterise the form of state from the position of anthropology, regardless of the fact that widely used definition or the form of state does not include the anthropological aspect.

The reasons of the providing the institution of power with the humane characteristics are determined. It is established that the identification of power with specific people, who occupy a high post, or political party is the main factor, which causes this phenomenon.

The practical significance of the anthropological approach is considered. It is applied during the legislative process, particularly in case of the establishment of statutory requirements to candidates to apply for posts. It is also reflected in the issues of racial, gender or national equity.

It is proved that anthropological approach is actively used in politics during the process of creation of political myths. It is important to keep in mind that the results of anthropological research of power can be used not for the right purpose, but to successfully manipulate social consciousness.

Key words: anthropology of power, origin of power, nature and essence of the phenomenon of power, anthropic characteristics of power, anthropologicalapproach to power. 